\title{
Phytochemical Constituents, and In vitro Antidiabetic and Antioxidant Properties of Various Extracts of Kenikir (Cosmos caudatus) Leaves
}

\author{
Muhamad Dea Firdaus ${ }^{1}$, Nina Artanti ${ }^{2}$, Muhammad Hanafi ${ }^{2}$, Rosmalena ${ }^{1, *}$
}

Muhamad Dea Firdaus ${ }^{1}$, Nina Artanti ${ }^{2}$, Muhammad Hanafi', Rosmalena ${ }^{1, *}$

'Department of Medicinal Chemistry, Faculty of Medicine, Universitas Indonesia, Depok 16424, INDONESIA.

${ }^{2}$ Research Center for Chemistry, Indonesian Institute of Sciences, Kawasan PUSPITEK

Serpong, South Tangerang, Banten, INDONESIA.

\section{Correspondence}

\section{Rosmalena}

Department of Medicinal Chemistry,

Faculty of Medicine, Universitas Indonesia,

Depok 16424, INDONESIA.

E-mail: rosmalena2018@gmail.com

History

- Submission Date: 28-01-2021;

- Review completed: 26-02-2021;

- Accepted Date: 12-03-2021.

DOI : 10.5530/pj.2021.13.114

Article Available online

http://www.phcogj.com/v13/i4

Copyright

(C) 2021 Phcogj.Com. This is an openaccess article distributed under the terms of the Creative Commons Attribution 4.0 International license.

\begin{abstract}
Type 2 diabetes mellitus (T2DM) is one of the most common degenerative disorders. For therapeutic use, herbs are commonly used in Indonesia for T2DM treatment, one of them is (Cosmos caudatus) kenikir's leaves. In previous studies, kenikir's leaves have high antidiabetic and antioxidant activity. However, a comparison of antidiabetic activity from many extracts of kenikir's leave is remain unclear. This study will compare the antidiabetic and antioxidant properties of various kenikir's leave extract. Kenikir's leaves are extracted by maceration methods for three days using three different solvents: boiling water, $50 \%$ ethanol, dan ethanol $100 \%$. Then, phenolic and flavonoid content will be measured, as well as antioxidant properties by DPPH radical scavenging activity assay, and antidiabetic properties by $\alpha$-glucosidase inhibition assay, also LCMS/MS will be used to predict the compound from each extract. The result shows that $50 \%$ ethanol extract has highest phenolic and flavonoid content than others. It also has significantly higher antioxidant $(p<0.05)$ and antidiabetic $(p<0.05)$ properties than others. Meanwhile, LCMS/MS result of $50 \%$ ethanol extract predicts 6 chemical component, that quercetin is the most dominant compound. $50 \%$ ethanol extract of kenikir's leaves is superior from other extracts on phenolic and flavonoid content, antioxidant properties, and antidiabetic properties.
\end{abstract}

Key words: $\alpha$-Glucosidase.

\section{INTRODUCTION}

Type 2 Diabetes Mellitus (T2DM) is one of the most prevalent metabolic disorders that characterize by chronic hyperglykemia. ${ }^{1}$ This condition leads to an increase in many adverse effects on glucose biochemistry pathway, including glucose oxidation, the formation of advanced glycation endproducts (AGE), and activation of polyol pathway. Consequently, that will give rise to free radical formation that will damage many organs and cause microvascular and microvascular complications, such as cardiomyopathy, retinopathy, neuropathy, and nephropathy. ${ }^{2}$ Antioxidant is one of the agents that can prevent T2DM complications by transfer its electron, thus free radicals become more stable and less toxic to the body. ${ }^{2,3}$ It is well known that herbs have abundant antioxidant components in it, thus have been widely used to treat many disorders including T2DM ${ }^{4}$, one of them is kenikir (Cosmos caudatus). ${ }^{5}$

Just like any other herbs, Kenikir has abundant organic compounds in it, especially polyphenol that often be linked with antidiabetic activity. 2,6 Previous studies have demonstrated that kenikir contains many active substances, such as flavonoid, saponin, alkaloid, tannin, and polyphenol. ${ }^{6}$ Other studies explained that $C$. caudatus water extract has a very high phenolic compound. ${ }^{7}$ A very high antioxidant activity was also detected in methanol and ethanol extract of kenikir. ${ }^{5}$ Moreover, $n$-hexane and ethanol extract have direct antidiabetic activity by inhibition of $\alpha$-glucosidase and $\alpha$-amylase enzyme that has a role in glucose absorption in the human body. ${ }^{5,78}$ Those extracts were known to have antidiabetic activity because have catechin, a-D-glucopyranoside, and a-tocopherol in it. Furthermore, dichloromethane extract also had an antihypertensive effect. ${ }^{7}$

Even though therapeutic effects of this plant as antioxidant and antidiabetic have been explained, the effect of solvent that is used for the extraction process towards antidiabetic activity has not been explained properly. Therefore, this study will compare antioxidant and antidiabetic activity of different extraction solvents from kenikir's leaves by in vitro study using DPPH radical scavenging assay and $\alpha$-glucosidase inhibition assay.

\section{METHODS}

\section{Plant material}

Plant materials of Cosmos caudatus leaves were collected from PUSPITEK LIPI Serpong, South Tangerang. Then, it was cleaned from foreign material and dried using vacuum oven at $50^{\circ} \mathrm{C}$. Dried sample was mashed and sieved to be uniform powder.

\section{Extraction process}

$14 \mathrm{~g}$ sample were extracted using maceration methods by 3 different solvents: warm water, $50 \%$ ethanol, and $96 \%$ ethanol, $15 \mathrm{~mL}$ each for three days. Next, it was filtered by filtration paper, then concentrated by rotary evaporator at $50^{\circ} \mathrm{C}, 150 \mathrm{rpm}$.

Cite this article: Firdaus MD, Artanti N, Hanafi M, Rosmalena. Phytochemical Constituents, and In vitro Antidiabetic and Antioxidant Properties of Various Extracts of Kenikir (Cosmos caudatus) Leaves. Pharmacog J. 2021;13(4): 890-895. 


\section{Phytochemistry screening}

\section{Alkaloids test}

$5 \mathrm{mg}$ extract, $0.1 \mathrm{~mL} \mathrm{HCl} 2 \mathrm{~N}$ and $0.9 \mathrm{ml}$ aquadest were added to the tube, then heat, filtered, and divided into 2 test tubes. Each tube was treated with Bouchardat's reagent and Mayer's reagent respectively. Formation of reddish brown and white color respectively indicated the presence of alkaloid. ${ }^{9,10}$

\section{Flavonoid test}

$4 \mathrm{mg}$ extract was dissolved by $3 \mathrm{~mL}$ ethanol and added to the tube. Added $0.1 \mathrm{mg}$ magnesium and 10 drops of concentrated $\mathrm{HCl}$. Formation of pink color indicated the presence of flavonoid. ${ }^{11}$

\section{Tannin test}

Next, few drops of $\mathrm{FeCl}_{3}$ were added. The presence of tannin is indicated by formation of dark blue or greenish black color. ${ }^{12}$

\section{Saponin test}

$5 \mathrm{mg}$ extract and $10 \mathrm{~mL}$ boiling water were added to the tube, then shook it for 10 seconds. After that, added 10 drops of $\mathrm{HCl} 2 \mathrm{~N}$ to the tube. Appearance of the foam showed the presence of saponin. ${ }^{11}$

\section{Terpenoid test}

$5 \mathrm{mg}$ extract was dissolved with $3 \mathrm{~mL}$ dichloromethane, then steamed it. After that, 6 drops of acetic acid and 3 drops of sulfuric acid were added to the tube. Blue-green color formation indicated the presence of terpenoid. ${ }^{13}$

\section{Total phenolic and flavonoid compounds}

Total phenolic concentration was measured by Folin-Ciocalteu methods with gallic acid as a standard. Meanwhile, total flavonoid was determined by aluminium chloride colorimetric assay with quercetin as a standard. ${ }^{3}$

\section{Antioxidant activity test: DPPH radical scavenging assay}

Antioxidant activity test is measured by $D P P H$-radical scavenging activity. $5 \mu \mathrm{L}$ of extract dissolved in $155 \mu \mathrm{L}$ ethanol, then mixed with $40 \mu \mathrm{L}$ DPPH and incubate for 30 minutes in dark room with room temperature. After that, read with microplate reader at $515 \mathrm{~nm}$ wavelength. Percentage of inhibition is measured by following formula: $\%$ Inhibition $=\frac{\left(\mathrm{Abs}_{\text {blank }}-\mathrm{Abs}_{\text {extract }}\right)}{\mathrm{Abs}_{\text {blank }}} \times 100 \%$

Next, the test was re-performed with different extract concentration, including 100, 50, 25, 12,5, and $6.25 \mathrm{ppm}$. The result would form a graph, that will be used to determine IC50 by linear regression methods.

\section{Antidiabetic activity test: a-glucosidase inhibition assay}

Antidiabetic activity test is measured by $\alpha$-glucosidase inhibition assay. $5 \mu \mathrm{L}$ of extract was mixed with $5 \mu \mathrm{L}$ DMSO and $45 \mu \mathrm{L}$ buffer phosphate. Then, added $25 \mu \mathrm{L}$ substrate and $25 \mu \mathrm{L}$ a-glucosidase enzyme, and incubated for 15 minutes. Next, added $95 \mu \mathrm{L}$ sodium bicarbonate $0.2 \mathrm{M}$ to terminate enzymatic activity. After that, read with microplate reader at $400 \mathrm{~nm}$ wavelength. Percentage of inhibition is measured by calculate extract $\left(\mathrm{s}_{1}\right)$, background extract $\left(\mathrm{s}_{0}\right)$, blank $\left(\mathrm{b}_{1}\right)$, and background blank $\left(b_{0}\right)$ by following formula:

$$
\% \text { Inhibition }=\frac{\left[\left(A_{b 1}-A_{b 0}\right)-\left(A_{s 1}-A_{s 0}\right)\right]}{\left(A_{b 1}-A_{b 0}\right)} \times 100 \%
$$

Next, the test was re-performed with different extract concentration, including 200, 150, 100, 50, and $25 \mathrm{ppm}$. The result would form a graph, that will be used to determine IC50 of antidiabetic activity by linear regression methods.

\section{LCMS/MS analysis}

LCMS/MS analysis will be performed using Waters Corporation Systems, where Liquid Chromatography (LC) specification is UPLC I-Class Plus System, while Mass Spectrometry (MS) specification is Xevo G2-Xs QTof Quadrupole Time-of-Flight Mass Spectrometry. LC condition including: using separation column; solvents is using $0.1 \%$ formic acid/water and acetonitrile +0.1 formic acid; $1 \mu \mathrm{L}$ injection volume; $0.3 \mathrm{~mL} / \mathrm{min}$ flow rate; and column temperature is $40^{\circ} \mathrm{C}$. Meanwhile, MS condition including: ESI ionization; positive polarity; $30 \mathrm{~V}$ Cone Voltage; $6.00 \mathrm{eV}$ and $10.00 \mathrm{eV}$ Collition energy; and precursor ion 100-1200 m/z. UNIFI Scientific Information System will be used to analyse the results.

\section{RESULTS}

\section{Phytochemical screening}

The results of phytochemical screening are shown that $96 \%$ ethanol extract has more diverse metabolite compounds than others. Those compounds are alkaloid, tannin, saponin, and terpenoid as shown in Table 1. However, flavonoid was detected only in 50\% ethanol extract.

\section{Total phenolic and flavonoid compounds}

The concentration results in $1,000 \mu \mathrm{g} / \mathrm{ml}$ extracts are shown as gallic acid equivalent for phenolic compound and quercetin equivalent for flavonoid compound. All of the extracts are contain both phenolic and flavonoid content that $50 \%$ ethanol extract is the highest one as shown in Figure 1.

\section{Antioxidant activity}

All of kenikir's leaves extracts demonstrated the capacity of DPPH free radical scavenging activity, with $50 \%$ ethanol extract exhibit the strongest antioxidant activity compared to other extracts. The mean inhibition activity of $50 \%$ ethanol extract was $84.036 \%$ (Figure 2a), that statistically significant compare to others $(\mathrm{p}<0.05)$. However, the difference between $96 \%$ ethanol and water extract was not statistically

Table 1: Phytochemical screening of kenikir.

\begin{tabular}{|cccc|}
\hline & Water & $50 \%$ ethanol & $96 \%$ ethanol \\
\hline Bouchardat Test & + & - & - \\
Mayer Test & - & + & + \\
Flavonoid Test & - & + & - \\
Tannin Test & + & + & ++ \\
Saponin Test & - & - & + \\
Terpenoid Test & - & - & + \\
\hline
\end{tabular}

\section{Phenol and Flavonoid Concentration}

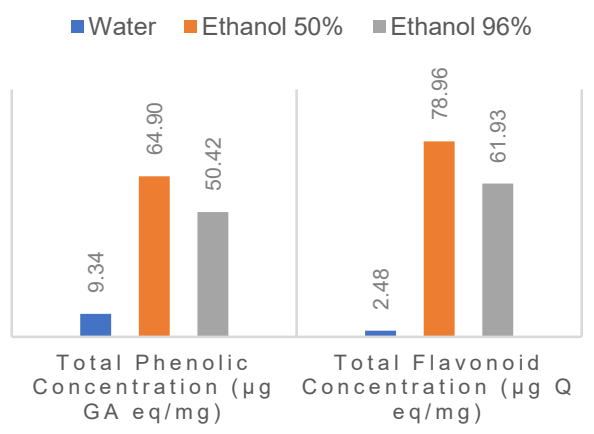

Figure 1: Total phenolic dan flavonoid of kenikir extract. 
significant ( $p>0.05$ ). The $50 \%$ ethanol extract had IC50 about 59,99 \pm $4,49 \mu \mathrm{g} / \mathrm{ml}$, that still significantly weaker than quercetin as a control (p $<0.05$ ), that had IC50 around 5,976 $\pm 0,08 \mu \mathrm{g} / \mathrm{ml}$ (Figure $2 \mathrm{~b}$ ).

\section{Antidiabetic activity}

All of kenikir's leaves extracts possessed the capacity of inhibiting the a-glucosidase enzyme, with $50 \%$ ethanol extract had the strongest inhibiting activity compare to other extracts. The mean inhibition of $50 \%$ ethanol extract was $61,8 \%$ (Figure $3 a$ ), that statistically significant compare to others $(p<0.05)$. However, $96 \%$ ethanol extract was not significantly stronger than water extract $(\mathrm{p}>0.05)$. The $50 \%$ ethanol extract had IC50 about $77,17 \pm 37,08 \mu \mathrm{g} / \mathrm{ml}$, that still significantly weaker than quercetin $(\mathrm{p}<0.05)$, that had IC50 about $1,38 \pm 0,433 \mu \mathrm{g} /$ $\mathrm{ml}$ (Figure 3b).

\section{LCMS/MS analysis}

18 bioactive components were found in the LCMS/MS analysis results of $50 \%$ ethanol, $96 \%$ ethanol, and water extracts as seen in chromatograms (Figure 4). As shown in Table 2, 50\% ethanol and 96\% ethanol extract had similar bioactive component, while water extract was different.
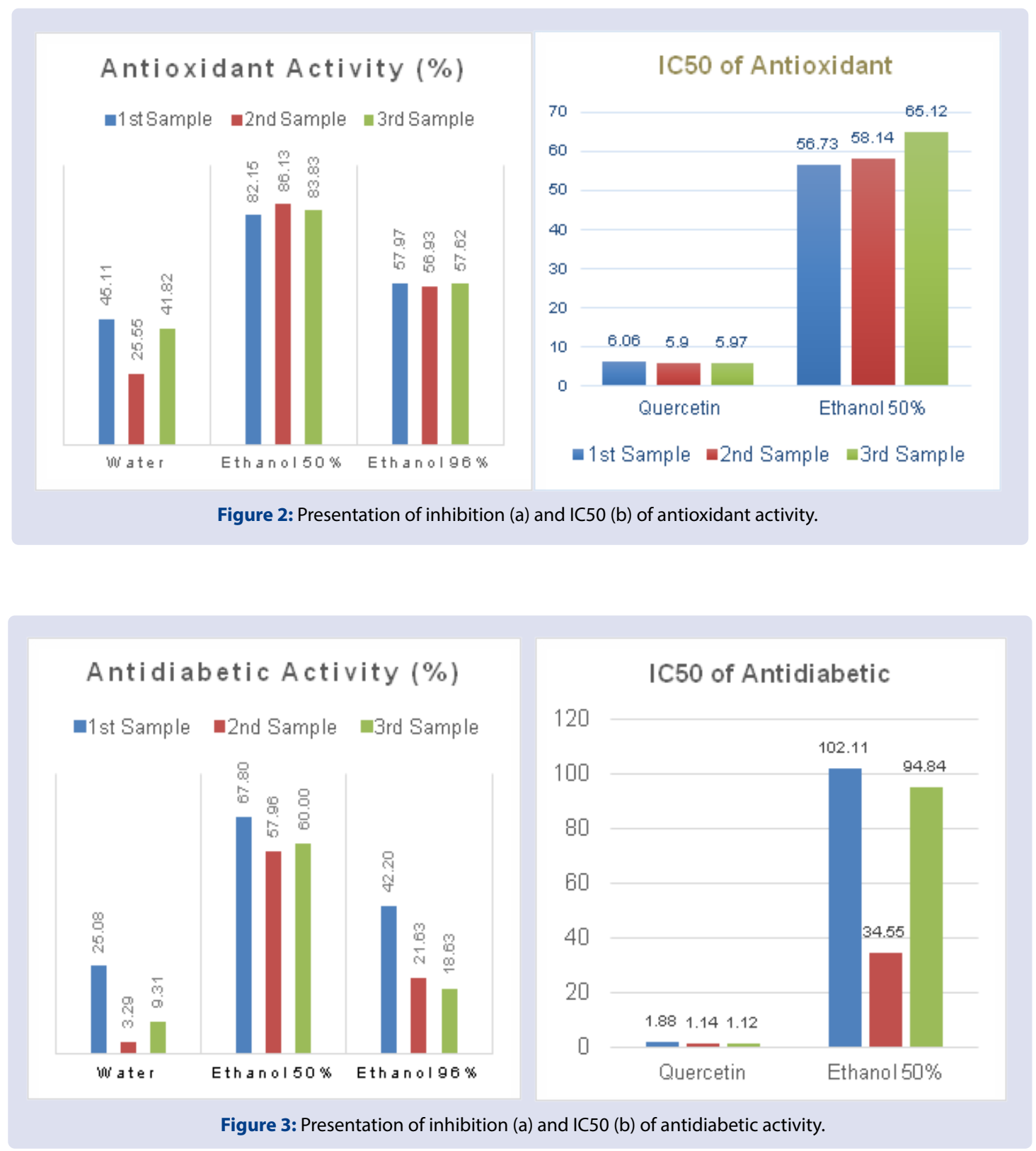


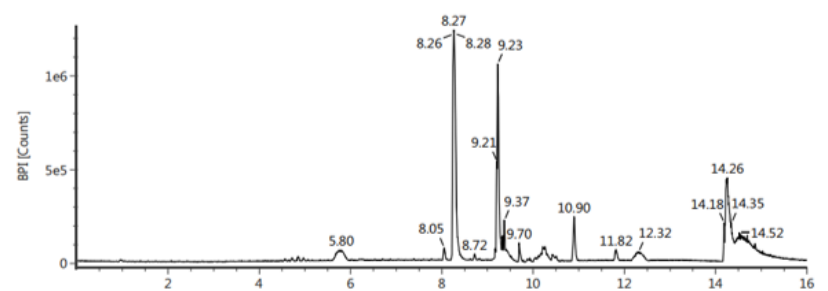

(a)

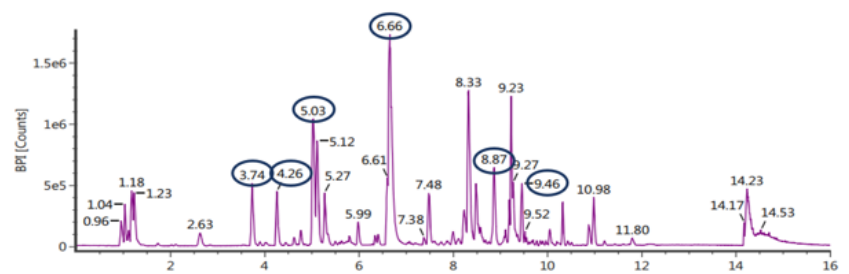

(c)

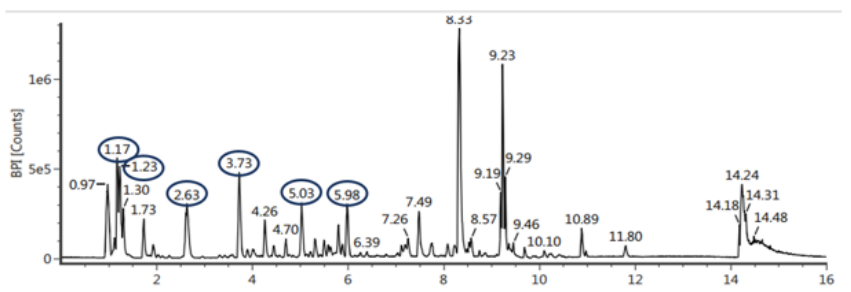

(b)

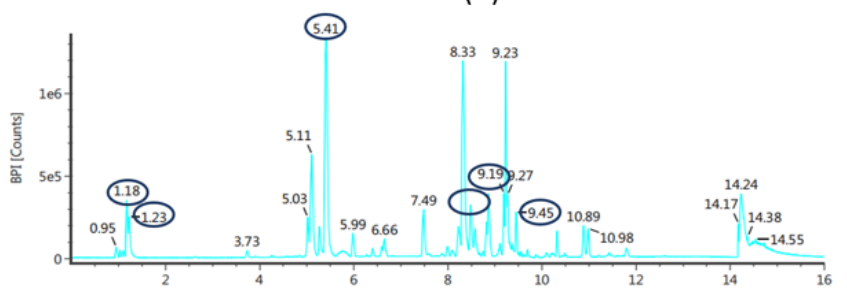

(d)

Figure 4: Cromatogram result of blank (a), water extract (b), 50\% ethanol extract (c), and 96\% ethanol extract (d).

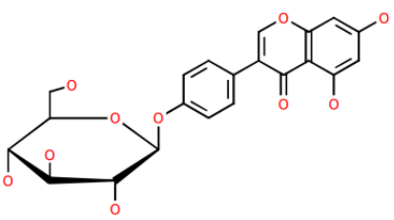

Genistin<smiles>CC(C)[C@H](N)C(=O)O</smiles>

Valine<smiles>Cc1nccc2c1C(O)OCC2</smiles>

Gentiatibetine<smiles>CC1(C)C[C@H](O)C[C@]2(C)OC(=O)C=C12</smiles>

Digiprolactone<smiles>O[C@@H]1C[C@@H]2CC[C@H](N2)[C@H]1O</smiles>

$2 \beta, 3 \beta$-Dihydroxy nortropan€<smiles>C=C1CCC2[C@@H](C2(C)C)[C@@]2(C)CC[C@@](C)(O)C12</smiles>

Spathulenol<smiles>O=c1c(O)c(-c2ccc(O)c(O)c2)oc2cc(O)cc(O)c12</smiles>

Quercetin

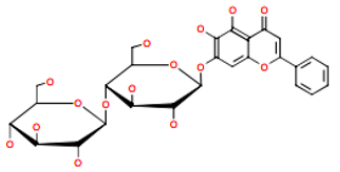

Oroxin B<smiles>Cc1cc2c(c(N)c1N)C(=O)c1cc(Cl)ccc1C2=O</smiles>

1,3,6-Trihydroxy-2methylanthraquinone-3O- $\beta$-D-glucopyranoside<smiles>NC(Cc1ccccc1)C(=O)O</smiles>

Phenylpropionic acid<smiles>C=C1/C=C/C(C)(C)C/C=C/C(C)=C/CC1</smiles>

$\delta$-Humulene

Figure 5: Chemical structure of bioactive compounds that have been revealed in kenikir extracts using LCMS/MS. 


\section{DISCUSSION}

The kenikir's leaves were extracted using different solvents to analyze the effect to its antioxidant and antidiabetic activity. This study used ethanol as a solvent for extracting samples because of its semipolar characteristic while warm water is a polar solvent. ${ }^{9}$ It is also one of the safe solvents that are allowed to be used in food ingredients together with ethyl acetate and acetone. ${ }^{3}$ Warm water was used because high temperatures will increase cell wall permeability and facilitate the extraction process. ${ }^{9}$ Combination of those solvents (50\% ethanol) is used to affect certain compounds that less soluble in $96 \%$ ethanol.

Phytochemical screening results showed kenikir's leaves bioactive components are alkaloids, flavonoids, saponin, tannin, and terpenoids that is parallel with previous studies. ${ }^{6,7}$ Those bioactive components are known to have medicinal properties, especially as the antioxidant and antidiabetic agents. Alkaloids are had antioxidant activity and play a role as the antidiabetic agent by down-regulating gluconeogenesis activity. ${ }^{5,14}$ Flavonoids can inhibit the formation of reactive oxygen species (ROS) and induce beta cell regeneration so can prevent T2DM complications. ${ }^{15}$ Saponin has antioxidant activity both in vitro and in vivo studies and also can reduce blood glucose level by inhibits glucose transportation in gastrointestinal tract. ${ }^{5,16}$ Tannin is also antidiabetic agent that can increase glycogenesis and decrease glucose absorption. ${ }^{5}$ Lastly, terpenoids are used for antidiabetic medication in various country. ${ }^{17}$ These screening results were not in parallel with quantitative test that more reliable. It might be due to many factors, including human error.

The results of total phenolic and flavonoid content were not in line with the previous study. Rahman et al demonstrated that ethanol extract had higher phenolic and flavonoid contents than $50 \%$ ethanol extract. ${ }^{18}$ That study also found that ethanol extract had stronger antioxidant activity. ${ }^{18}$ According to previous studies, antioxidant activity is often linked with phenolic compounds, that also include flavonoids. ${ }^{6}$ These unparalleled results with the previous study might occur because of many differences, such as harvesting periods, environmental and weather conditions, and environmental temperatures. ${ }^{19}$ In this study, 50\% ethanol extract, that is semipolar extract, was more powerful in both total phenolic, total flavonoids, and antioxidant activity than any other extracts. Its IC50 of antioxidant activity was also classified as a strong antioxidant based on Fidrianny I. ${ }^{20}$ This biological property is beneficial for preventing T2DM complications. ${ }^{2}$

Antidiabetic activity results of kenikir extracts as a-glucosidase inhibitor showed similar result, where $50 \%$ ethanol extract had the greatest inhibition percentage. The IC50 of antidiabetic activity was $77,17 \pm 37,08 \mu \mathrm{g} / \mathrm{ml}$, that is still lower than quercetin as the positive control but parallel with Chan ECW that got the IC50 of a-glucosidase inhibition around $58 \mathrm{ppm}$ for ethanol extract. ${ }^{5}$ This results might indicate that antidiabetic components from kenikir extract are more likely to dissolve in $50 \%$ ethanol solvent.

The LCMS/MS analysis profiling analysis of 3 different kenikir's leaves extracts revealed 12 bioactive compounds that are predominantly secondary metabolites. The compounds were found to have various biological properties, especially antioxidant and antidiabetic activity (Table 3). Water extract was revealed 2 compounds, that is genistin and gentiatibetine. Both of them had weak antioxidant activity ${ }^{21}$, while only genistin had antidiabetic property. ${ }^{22,23} 50 \%$ ethanol extract had 6 compounds that have more diverse biological potency. Quercetin is one of the compounds that are a strong antioxidant agent and also have stronger antidiabetic activity than acarbose. ${ }^{24-27}$ This compound is the main component of ethanol extracts according to detector response in Table 2 that correlated with its high antioxidant and antidiabetic activity. Other compounds are: oroxin $\mathrm{B}$, that have weak antioxidant activity ${ }^{28}$; Stearidonic acid and Phenylpropionic acid that have antidiabetic activity ${ }^{29-31}$; and 1,3,6-Trihydroxy-2-methylanthraquinone-3-O- $\beta$-Dglucopyranoside, a novel compound that its biological properties have not been explained clearly and might be a potential compound because its glucopyranoside group that has antidiabetic activity. ${ }^{7}$ Meanwhile, $96 \%$ ethanol extract had similar compounds with 50\% ethanol extract, except spathulenol that have antidiabetic activity greater than acarbose. ${ }^{32}$

Table 3: Bioactive components in kenikir extract and its beneficial potency.

\begin{tabular}{|c|c|c|c|c|}
\hline No. & Compound & Chemical Group & Biological Properties & Studies \\
\hline \multicolumn{5}{|c|}{ Water Extract } \\
\hline 1 & Genistin & Isoflavone & $\begin{array}{l}\text { Anticancer, antioxidant, and antidiabetic agent } \\
\text { Antioxidant agent }(\mathrm{IC} 50=180 \mathrm{ppm}) \\
\text { Antidiabetic agent }(\mathrm{Ki}=5,7 \times 10-5 \mu \mathrm{g} / \mathrm{ml})\end{array}$ & $\begin{array}{l}\text { Moseti } \mathrm{D} \text {, et } a l^{23} \\
\text { Ruslan } \mathrm{K} \text {, et } a l^{22} \\
\text { Moseti } \mathrm{D} \text {, et } a l^{23}\end{array}$ \\
\hline 2 & Gentiatibetine & Alkaloid & $\begin{array}{l}\text { Anticancer, antibacterial, and antioxidant agent } \\
50 \% \text { ethanol Extract }\end{array}$ & Bayliak, et $a l^{21}$ \\
\hline 1 & Quercetin & Flavonols & $\begin{array}{l}\text { Anticancer and antioxidant agent } \\
\text { Therapeutic Agent for CVD and degenerative disorders } \\
\text { a-glucosidase inhibitor greater than acarbose } \\
\text { Antioxidant agent by inhibits polyol pathway } \\
\text { Antilipidemic agent }\end{array}$ & $\begin{array}{l}\text { Lesjak, et } a l^{24} \\
\text { Serban, et al } \\
\text { Soltesova, et } a^{26} \\
\text { Soltesova, et } a l^{26} \\
\text { Srinivasana } \mathrm{P} \text {, et } \text { al }^{27}\end{array}$ \\
\hline 2 & $\begin{array}{l}\text { 1,3,6-Trihydroxy-2- } \\
\text { methylanthraquinone-3- } \\
\text { O- } \beta \text {-D-glucopyranoside }\end{array}$ & Methyl-Glycoside & \multicolumn{2}{|l|}{ Have not studied yet } \\
\hline 3 & Oroxin B & Flavonoid & $\begin{array}{c}\text { Antidiabetic in O. indicum } \\
\text { Its isomer (Oroxin D and C) are antidiabetic compound } \\
\text { Weak antioxidant activity }\end{array}$ & $\begin{array}{l}\text { Dong Y, et } a l^{28} \\
\mathrm{Li} \mathrm{G}, \text { et } a l^{33} \\
\text { Dong Y, et } a l^{28}\end{array}$ \\
\hline 4 & $\delta$-Humulene & Terpenoid & Its isomer ( $\alpha$-humulene) is anticancer agent & Chen $\mathrm{H}$, et $a l^{34}$ \\
\hline 5 & Stearidonic acid & Omega-3 PUFA & $\begin{array}{l}\text { Antidiabetic agent } \\
\text { Antitumor agent and lipid regulator } \\
\text { Anti-inflammation agent }\end{array}$ & $\begin{array}{l}\text { Gao YX, et al }{ }^{29} \\
\text { Yan Li, et al }{ }^{35} \\
\text { Sung J et al }\end{array}$ \\
\hline 6 & Phenylpropionic acid & Carboxylic Acid & Antidiabetic dan antithrombotic agent (agonist GPR40) & $\begin{array}{l}\text { Kuranov } \mathrm{SO} \text {, et } a l^{30} \text { dan } \mathrm{Li} \mathrm{Z} \text {, } \\
\qquad{\text { et } a l^{31}}^{3}\end{array}$ \\
\hline & & & $96 \%$ ethanol Extract & \\
\hline 1 & Spathulenol & Tricyclic Alcohol & $\begin{array}{l}\text { Dominant compound (87\%) in Psidium gineense } \\
\text { a-glucosidase inhibitor (IC50 }=1,18 \mu \mathrm{g} / \mathrm{ml} \text { ) greater than acarbose }\end{array}$ & Bahadori, et $a^{32}$ \\
\hline
\end{tabular}




\section{CONCLUSION}

The use of different solvents in the extraction process will affect the antioxidant and antidiabetic activity of the extract. In this study, $50 \%$ ethanol extract of kenikir's leaves is the best solvent that has the highest total phenolic and flavonoid concentration, antioxidant activity, and antidiabetic activity than $96 \%$ ethanol and water extract. LCMS/MS analysis of $50 \%$ ethanol extract shown high amount of quercetin that had been demonstrated as a potent antioxidant and antidiabetic agent.

\section{REFERENCES}

1. Tandi J, As'ad A, Natzir Z, Bukhari A. Test of ethanol extract red gedi leaves (albelmoschus manihot. (I.) medik) in white rat (rattus norvegicus) type 2 diabetes mellitus. J Sci. 2016;30(4):84-94.

2. Shi G-J, Li Y, Cao O-H, Wu H-X, Tang X-Y, Gao X-H, et al. In vitro and in vivo evidence that quercetin protects against diabetes and its complications: A systematic review of the literature. Biomed Pharmacother. 2019;109:1085-99.

3. Dewijanti ID, Mangunwardoyo W, Artanti N, Hanafi M. Bioactivities of salam leaf (Syzygium polyanthum (wight) walp). In: AIP Conference Proceeding. AIP Publishing LLC; 2019.

4. Chikezie PC, Ojoako OA, Nwufo KC. Overview of anti-diabetic medicinal plants: the nigerian research experience. J Diabetes Metab. 2015;6(6):1-7

5. Chan EWC, Wong SK, Chan HT. Ulam herbs of oenanthe javanica and cosmos caudatus: an overview on their medicinal properties. J Nat Remedies. 2016;16(4):137-47.

6. Perumal V, Hamid AA, Ismail A, Saari K, Abas F, Ismail IS, et al. Effect of cosmos caudatus kunth leaves on the lipid profile of a hyperlipidemia induced animal model. J Food Chem Nutr. 2014;2(2):43-51.

7. Moshawih S, Cheema MS, Achmad Z, Zakaria ZA, Hakim MN. A comprehensive review on cosmos caudatus (ulam raja): pharmacology, ethnopharmacology, and phytochemistry. Int Res J Educ Sci. 2017;1(1):14-31.

8. Brunton LL, Knollmann BC, Hilal-Dandan R. Goodman and gilman's: the pharmacological basis of therapeutics. 13th editi. Philladelphia: Mc Graw Hill Education; 2017.

9. Prasasty VD, Haryani B, Hutagalung RA, Mulyono N, Yazid F, Rosmalena R, et al. Evaluation of Antioxidant and Antidiabetic Activities from Red Seaweed (Eucheuma cottonii). Syst Revies Pharacy. 2019;10(1):276-88.

10. Bouteldja R, Doucene R, Bouzid R, Moulay M, Aggad H. Biological activity of aristolochia longa I. against some pathogenic bacteria and phytochemical screening. Lucr Stiint. 2019;52(3).

11. Gul R, Jan SU, Faridullah S, Sherani S, Jahan N. Preliminary Phytochemical Screening, Quantitative Analysis of Alkaloids, and Antioxidant Activity of Crude Plant Extracts from Ephedra intermedia Indigenous to Balochistan. Sci Wolrd J. 2017;5873648:1-7.

12. Rani VP, Mirabel LMRL, Priya KS, Nancy AA, Kumari GM. Phytochemical, Antioxidant and Antibacterial Activity of Aqueous Extract of Borassus Flabellifer (L.). Int J Sci Res Sci Technol. 2018;4(2):405-10.

13. Ahmad W, Singh S, Kumar S. Phytochemical Screening and antimicrobial study of Euphorbia hirta extracts. J Med Plants Stud. 2017;5(2):183-6.

14. Balanquit B, Fuentes R. Preliminary Phycochemical Screening and Antioxidant Activity of Some Brown Algae Sargassum Species From Lawaan, Eastern Samar. J Nat Stud. 2015;14(1):12-21.

15. Trilestari FN, Subagus W, Abdul R. Aktivitas antioksidan ekstrak etanolik berbagai jenis sayuran serta penentuan kandungan fenolik dan flavonoid totalnya. J Media Farm Jakarta. 2014;11(2):167-78.

16. Chen Y, Miao Y, Huang L, Li J, Sun H, Zhao Y. Antioxidant activities of saponins extracted from Radix Trichosanthis : an in vivo and in vitro evaluation. BMC Complement Altern Med. 2014;14(1):86.

17. Nazaruk J, Borzym-Kluczyk M. The role of triterpenes in management of diabetes mellitus and its complications. Phytochem Rev. 2015;14(4):675-90.
18. Rahman HA, Saari N, Abas F, Ismail A, Mumtaz MW, Hamid AA. Antiobesity and antioxidant activities of selected medicinal plants and phytochemical profiling of bioactive compounds. Int J Food Prop. 2017;20(11):2616-29.

19. Chang Y-L, Lin J-T, Lin H-L, Liao P-L, Wu P-J, Yang D-J. Phenolic compositions and antioxidant properties of leaves of eight persimmon varieties harvested in different periods. Food Chem. 2019;289:74-83.

20. Fidrianny I, Darmawati A, Sukrasno. Antioxidant Capacities from Different Polarities Extracts of Cucurbitaceae Leaves Using FRAP, DPPH Assay and Corelation with Phenolic, Flavonoid, Carotenoid Content. Int J Pharm Pharm Sci. 2014;6:858-62.

21. Bayliak, Maria M, Nadia I, Burdyliuk, Volodymyr I. Effects of $\mathrm{pH}$ on antioxidant and prooxidant properties of common medicinal herbs. Open Life Sci. 2016;11(1):298-307.

22. Ruslan K, Happyniar S, Firdrianny I. Antioxidant potential of two varieties of Sesamum indicum L. collected from indonesia. J Taibah Univ Med Sci. 2018;13(3):211-8.

23. Moseti D, Regassa A, Kim W-K. Molecular Regulation of Adipogenesis and Potential Anti-Adipogenic Bioactive Molecules. Int $\mathrm{J}$ Mol Sci. 2016;17(1):124.

24. Lesjak M, Beara I, Simin N, Pintać D, Majkić T, Bekvalac K, et al. Antioxidant and anti-inflammatory activities of quercetin and its derivatives. J Funct Foods. 2018;40:68-75.

25. Serban MC, Sahebkar A, Zanchetti A, Mikhailidis DP, Howard G, Anta $D$, et al. Effects of quercetin on blood pressure: A systematic review and meta-analysis of randomized controlled trials. J Am Heart Assoc. 2016;5(7):e002712.

26. Soltesova-Prnova M, Milackova I, Stefek M. 3' -O-(3-Chloropivaloyl) quercetin, $\alpha$-glucosidase inhibitor with multi-targeted therapeutic potential in relation to diabetic complications. Chem Pap. 2016;70(11):1439-44.

27. Srinivasana P, Vijayakumara S, Kothandaraman S, Palania M. Antidiabetic activity of quercetin extracted from Phyllanthus emblica $\mathrm{L}$. fruit: In silico and in vivo approaches. J Pharm Anal. 2018;8(2):109-18.

28. Dong Y, Zhang B, Sun W, Xing Y. Intervention of Prediabetes by Flavonoids From Oroxylum indicum. In: Bioactive Food as Dietary Interventions for Diabetes. 2nd editio. Cambridge: Academic Press; 2019. p. 559-75.

29. Gao Y-X, Fan C, Tan X, Zhang J, Wang J. Stearidonic acid promotes insulin secretion via stimulation of $G$ protein-coupled receptor 40 in MIN6 pancreatic $\beta$-cells. J Funct Foods. 2019;60:103450.

30. Kuranov SO, Luzina OA, Onopchenko O, Pishel I, Zozuly S, Gureev $M$, et al. Exploring bulky natural and natural-like periphery in the design of p-(benzyloxy)phenylpropionic acid agonists of free fatty acid receptor 1 (GPR40). Bioorg Chem. 2020;99:103830.

31. Li Z, Xu X, Liu R, Deng F, Zeng X, Zhang L. Nitric oxide donor-based FFA1 agonists: Design, synthesis and biological evaluation as potential anti-diabetic and anti-thrombotic agents. Bioorganic Med Chem. 2018;26(15):4560-6.

32. Bahadori MB, Dinparast L, Zengin G, Sarikurkcu C, Bahadori S, Asghari B, et al. Functional components, antidiabetic, anti-Alzheimer's disease, and antioxidant activities of Salvia syriaca L. Int J Foor Prop. 2017;20(81761-72).

33. Li G, Wang G, Tong Y, Zhu J, Yun T, Ye X, et al. Concise synthesis and antidiabetic activity of natural flavonoid glycosides, oroxins $C$ and $\mathrm{D}$, isolated from the seeds of Oroxylum indium. J Chem Res. 2020;1747519820927966.

34. Chen H, Yuan J, Hao J, Wen Y, L Y, Chen L, et al. $\alpha$-Humulene inhibits hepatocellular carcinoma cell proliferation and induces apoptosis through the inhibition of Akt signaling. Food Chem Toxicol. 2019;134:110830.

35. Yan Li, Wang K, Zou Q, Jiang Y, Zhou C, Zheng J. ITE Suppresses Angiogenic Responses in Human Artery and Vein Endothelial Cells: Differential Roles of AhR. Reprod Toxicol. 2017;74:181-8. 